Atmos. Chem. Phys., 10, 9237-9250, 2010

www.atmos-chem-phys.net/10/9237/2010/

doi:10.5194/acp-10-9237-2010

(C) Author(s) 2010. CC Attribution 3.0 License.

\title{
Role of dust alkalinity in acid mobilization of iron
}

\author{
A. Ito ${ }^{1}$ and Y. Feng ${ }^{2}$ \\ ${ }^{1}$ Research Institute for Global Change, JAMSTEC, Yokohama, Kanagawa, 236-0001, Japan \\ ${ }^{2}$ Scripps Institution of Oceanography, University of California, San Diego, La Jolla, CA 92093-0221, USA
}

Received: 23 February 2010 - Published in Atmos. Chem. Phys. Discuss.: 21 April 2010

Revised: 1 September 2010 - Accepted: 24 September 2010 - Published: 1 October 2010

\begin{abstract}
Atmospheric processing of mineral aerosols by acid gases (e.g., $\mathrm{SO}_{2}, \mathrm{HNO}_{3}, \mathrm{~N}_{2} \mathrm{O}_{5}$, and $\mathrm{HCl}$ ) may play a key role in the transformation of insoluble iron ( $\mathrm{Fe}$ in the oxidized or ferric (III) form) to soluble forms (e.g., Fe(II), inorganic soluble species of $\mathrm{Fe}(\mathrm{III})$, and organic complexes of iron). On the other hand, mineral dust particles have a potential of neutralizing the acidic species due to the alkaline buffer ability of carbonate minerals (e.g., $\mathrm{CaCO}_{3}$ and $\mathrm{MgCO}_{3}$ ). Here we demonstrate the impact of dust alkalinity on the acid mobilization of iron in a three-dimensional aerosol chemistry transport model that includes a mineral dissolution scheme. In our model simulations, most of the alkaline dust minerals cannot be entirely consumed by inorganic acids during the transport across the North Pacific Ocean. As a result, the inclusion of alkaline compounds in aqueous chemistry substantially limits the iron dissolution during the long-range transport to the North Pacific Ocean: only a small fraction of iron $(<0.2 \%)$ dissolves from hematite in the coarse-mode dust aerosols with $0.45 \%$ soluble iron initially. On the other hand, a significant fraction of iron (1-2\%) dissolves in the fine-mode dust aerosols due to the acid mobilization of the iron-containing minerals externally mixed with carbonate minerals. Consequently, the model quantitatively reproduces higher iron solubility in smaller particles as suggested by measurements over the Pacific Ocean. It implies that the buffering effect of alkaline content in dust aerosols might help to explain the inverse relationship between aerosol iron solubility and particle size. We also demonstrate that the iron solubility is sensitive to the chemical specification of iron-containing minerals in dust. Compared with the dust sources, soluble iron from combustion sources contributes to a relatively marginal effect for de-
\end{abstract}

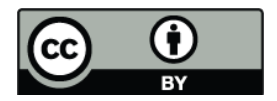

Correspondence to: A. Ito (akinorii@jamstec.go.jp) position of soluble iron over the North Pacific Ocean during springtime. Our results suggest that more comprehensive data for chemical specificity of iron-rich dust is needed to improve the predictive capability for size-segregated soluble iron particles.

\section{Introduction}

Iron $(\mathrm{Fe})$ is an essential nutrient for marine phytoplankton (Martin et al., 1994; Mills et al., 2004). Most photosynthetic aquatic organisms can take up iron only in the dissolved form. Thus although the iron-containing soil dust mobilized from arid regions supplies the majority of iron from the atmosphere to the oceans, the key flux in terms of the biogeochemical response to atmospheric deposition is the amount of soluble or bioavailable iron (Fung et al., 2000; Jickells et al., 2005; Mahowald et al., 2009; Baker and Croot, 2010). It has been proposed that atmospheric processing of mineral aerosols by anthropogenic pollutants (mainly sulfuric acid formed from oxidation of $\mathrm{SO}_{2}$ ) may transform insoluble iron into soluble forms (Zhu et al., 1992; Zhuang et al., 1992; Meskhidze et al., 2003).

The dissolution of dust minerals strongly depends on the solution $\mathrm{pH}$ during the chemical processing. In a comprehensive modeling study, Meskhidze et al. (2005) developed a specific mechanism, which described the mobilization of iron in mineral dust by anthropogenic pollutants, and applied it to study the East Asian dust outflows. Solmon et al. (2009) implemented the iron dissolution scheme of Meskhidze et al. (2005) in a chemical transport model. Both Meskhidze et al. (2005) and Solmon et al. (2009) predicted insignificant amounts of the dissolved iron during major dust events but a significant deposition of soluble iron during smaller dust activities in the transpacific transport. On the

Published by Copernicus Publications on behalf of the European Geosciences Union. 
other hand, mineral dust aerosols originating from the Asian deserts may exhibit a strong buffering ability by neutralizing the acidic pollutants encountered during the long-range transport (Iwasaka et al., 1988; Song and Carmichael, 1999, 2001; Tang et al., 2004). Recently, McNaughton et al. (2008) and Fairlie et al. (2009) have argued that dust does not acidify in the free troposphere generally. Their results indicate that iron mobilization may be limited to the small dust particles (radius $<1 \mu \mathrm{m}$ ) with very low initial alkalinity, because the uptake of acid gases on large mineral aerosols is much slower than that assumed by Meskhidze et al. (2005). On a single particle basis, only dust particles internally mixed with carbonate minerals can be buffered in this manner (Gao and Anderson, 2001). Sullivan et al. (2007) found that submicron dust particles could become very acidic by reacting with sulfuric acid during the early stage of the transport. They showed clear differences in the temporal changes of the secondary acid reaction products between dust particles rich in calcite and aluminosilicates. Their results imply that sulphate is highly associated with aluminosilicate-rich dust while nitrate is mixed with calcium-rich dust. Sulphate-dust peaks in the submicron mode while nitrate-dust peaks in the supermicron.

Previous studies have suggested higher iron solubility in smaller particles (Siefert et al., 1999; Hand et al., 2004; Baker and Jickells, 2006). Baker and Jickells (2006) attributed the relationship between iron solubility and particle size to a physical control (i.e., larger surface area to volume ratio of smaller aerosol particles). However, the solubility of iron may not be a simple function of the surface-area-tovolume ratio (Baker and Croot, 2010; Buck et al., 2010). For instance, smaller particles could go through more thorough chemical processing due to a longer residence time in the atmosphere, which in turn results in higher solubility (Zhuang et al., 1992; Hand et al., 2004). In addition, cloud processing, which may involve radical reactions in liquid phase, has been suggested to increase the soluble iron particles in the fine mode (Zhu et al., 1992; Shi et al., 2009). The mineralogy of iron also influences the particulate iron solubility and may contribute to the size dependence of the soluble ironrich dust (Claquin et al., 1999; Cwiertny et al., 2008; Journet et al., 2008; Schroth et al., 2009). Compared to mineral dust aerosols, iron from combustion sources is suggested to be more soluble, and found more frequently in smaller particles (Chuang et al., 2005; Guieu et al., 2005; Sedwick et al., 2007; Sholkovitz et al., 2009).

Here we use a global aerosol chemistry transport model to investigate the deposition of the dissolved iron during the long-range transport of mineral dust over the North Pacific Ocean. By incorporating a specific mineral aerosol dissolution scheme into the detailed aerosol chemistry model, we provide a theoretical examination of the effects of dust alkalinity on the acid mobilization of iron. In the following, Section 2 describes the atmospheric aerosol chemistry model, mineral aerosol dissolution scheme and iron emission data sets from both dust and combustion sources. Four numerical experiments are conducted to examine the impact on iron solubility due to assumptions about mixing states of mineral aerosols and the mineralogy of iron. Section 3 examines the sensitivity of the simulated soluble iron from the four model experiments as well as comparisons with observations. Section 4 presents a summary of our findings.

\section{Model approach}

\subsection{Atmospheric aerosol chemistry transport model}

We use an aerosol chemistry version of the Integrated Massively Parallel Atmospheric Chemical Transport (IMPACT) model (Rotman et al., 2004; Liu et al., 2005; Feng and Penner, 2007; Ito et al., 2009) as a framework for this study. The model is driven by assimilated meteorological fields for the year of 2001 from the Goddard Earth Observation System (GEOS) of the NASA Global Modeling and Assimilation Office (GMAO). Simulations were performed at a one-hour temporal resolution on a horizontal resolution of $2.0^{\circ} \times 2.5^{\circ}$ with 48 vertical layers. The model was spun up for two months before the production runs. Emissions of primary particles and precursor gases, chemistry of gas-phase, heterogeneous, and aqueous-phase reactions including mineral dissolution scheme, gravitational settling, dry and wet depositions, are simulated.

An online sulfur model is applied to predict the concentrations of $\mathrm{SO}_{2}, \mathrm{SO}_{4}^{2-}$ (represented in 5 aerosol size bins or sections: $<0.05 \mu \mathrm{m}, 0.05-0.63 \mu \mathrm{m}, 0.63-1.25 \mu \mathrm{m}, 1.25-2.5 \mu \mathrm{m}$, $2.5-10 \mu \mathrm{m}$ in radius), $\mathrm{H}_{2} \mathrm{O}_{2}$ and DMS (Liu et al., 2005). The concentrations of oxidants (i.e., $\mathrm{HO}_{\mathrm{x}}\left(\equiv \mathrm{OH}+\mathrm{HO}_{2}\right)$ and $\left.\mathrm{O}_{3}\right)$ are derived from a full gas-phase chemistry simulation using the same emission data and meteorological fields (Ito et al., 2007, 2009). Sea salt and mineral dust aerosols are considered in 4 size bins (radius: $<0.63,0.63-1.25,1.25-2.5$, and $2.5-10 \mu \mathrm{m})$. For this study, the total amount of particulate sulfate condensed on the large dust particles (radius $>1.25 \mu \mathrm{m})$ is determined by the available particle surface area (Nishikawa et al., 1991; Song and Carmichael, 1999, 2001; Zhang et al., 2000).

Since accurately solving the dynamic mass transfer equations over the entire aerosol size range is computationally expensive, Capaldo et al. (2000) developed a hybrid method which applies the thermodynamic equilibrium assumption to the fine aerosol mode and the dynamic approach to the coarse aerosol mode. Feng and Penner (2007) have demonstrated the importance of using such a hybrid dynamical approach in the calculation of nitrate and ammonium aerosols in global chemical transport models. Therefore the heterogeneous uptake of nitrate and ammonium by aerosol mixtures is interactively simulated in our model following the hybrid dynamical approach (Feng and Penner, 2007). Specifically, a thermodynamic equilibrium model (Jacobson, 1999) is applied for the 
Table 1. Constants Used to Calculate Mineral Dissolution/Precipitation Rates.

\begin{tabular}{lllllll}
\hline Number & Mineral & Rate Constant $K_{i}\left(\mathrm{~mol}_{\left.\text {mineral dissolved } \mathrm{m}^{-2} \mathrm{~s}^{-1}\right)} m_{i}\right.$ & $A_{i}\left(\mathrm{~m}^{2} \mathrm{~g}^{-1}\right)$ & $W_{i}(\%)$ & Reference \\
\hline RS1 & Calcite & Equilibrium & & & 11 & Meng et al. (1995) \\
RS2 & Magnesite & $4.4 \times 10^{-5} \exp [2400(1 / 298-1 / T)]$ & 1.0 & 1.0 & 5.5 & Chou et al. (1989) \\
RS3 & Hematite & Stage I $(0-0.8 \%$ of total oxide dissolved) & 0.5 & 100 & 5.0 & Azuma and Kametani (1964); \\
& & $4.4 \times 10^{-12} \exp [9200(1 / 298-1 / T)]$ & & Zinder et al. (1986); Blesa et al. (1994); \\
& & Stage II $(0.8-40 \%$ of total oxide dissolved) & & & Cornell and Schwertmann (1996); \\
& & $1.8 \times 10^{-11} \exp [9200(1 / 298-1 / T)]$ & & Skopp (2000) \\
& & Stage III $(40-100 \%$ of total oxide dissolved) & & & Tessier (1990); Nagy (1995); \\
RS4 & $3.5 \times 10^{-12} \exp [9200(1 / 298-1 / T)]$ & & & & Skopp (2000); Journet et al. (2008) \\
\hline
\end{tabular}

gas-aerosol partitioning in the fine mode (radius $<0.63 \mu \mathrm{m}$ ), while the concentrations of gaseous species and aerosols in the coarse aerosol mode (radius $>0.63 \mu \mathrm{m}$ ) are determined by dynamically solving the mass transfer equations. In the thermodynamic equilibrium/mass transfer calculations, sulfate, sea salt and mineral dust aerosols were assumed to be internally mixed in each size bin (Feng and Penner, 2007). Thus particles in the same size bins have the same chemical composition in aerosol mixture.

\subsection{Mineral aerosol dissolution}

A mineral aerosol dissolution scheme is introduced to the aerosol chemistry in the global model. We explicitly treat the dissolution/precipitation of two carbonate minerals (i.e., calcite and magnesite). The most likely clay minerals for carbonates are calcite $\left(\mathrm{CaCO}_{3}\right)$ and dolomite $\left(\mathrm{CaMg}\left(\mathrm{CO}_{3}\right)_{2}\right)$ (Andronova et al., 1993; Shao et al., 2007). Since the dissolution rate of dolomite is much faster than magnesite $\left(\mathrm{MgCO}_{3}\right)$, the dissolution rate of magnesium is thus controlled by the latter (Chou et al., 1989). Analysis of the ion charge balance based on airborne aerosol measurements suggests that significant fractions of the observed $\mathrm{Ca}^{2+}$ and $\mathrm{Mg}^{2+}$ are in the form of carbonates $\left(\mathrm{CaCO}_{3}\right.$ and $\left.\mathrm{MgCO}_{3}\right)$ (Maxwell-Meier et al., 2004).

The dissolution/precipitation of the calcite $\left(\mathrm{CaCO}_{3}\right)$ is assumed to be in thermodynamic equilibrium (RS1 in Table 1). The dissolved $\mathrm{Ca}$ is distributed among 4 possible solids $\left(\mathrm{CaCO}_{3}, \mathrm{CaSO}_{4}, \mathrm{Ca}\left(\mathrm{NO}_{3}\right)_{2}\right.$, and $\left.\mathrm{CaCl}_{2}\right)$ or the aqueous-phase species $\left(\mathrm{Ca}^{2+}\right)$. The relative amount of each of these species is calculated interactively by the thermodynamic module (Jacobson, 1999).

Magnesite $\left(\mathrm{MgCO}_{3}\right)$ dissolution is treated explicitly as a kinetic process depending on $\mathrm{pH}$, chemical composition of the aerosol solution coated on dust particles, and the ambient temperature. For kinetically-controlled dissolution rate of the mineral $\left(R_{i}\right)$, we adopt the formulation of Lasaga et al. (1994):

$R_{i}=K_{i}(T) \times a\left(H^{+}\right)^{m_{i}} f\left(\Delta G_{i}\right) \times A_{i} \times W_{i}$

where $K_{i}$ is the temperature $(T)$ dependent reaction coefficient (moles dissolved $\mathrm{m}^{-2}$ of mineral $\mathrm{s}^{-1}$ ) for mineral $i$, $a\left(H^{+}\right)$is the $H^{+}$activity, $m_{i}$ is an empirical parameter, $f$ is a function of Gibbs free energy change of a particular mineral dissolution reaction $\left(\Delta G_{i}\right)$, which accounts for the effect of the solution saturation state on dissolution rates (Cama et al., 1999), $A_{i}$ is the specific surface area of mineral in units of $\mathrm{m}^{2} \mathrm{~g}^{-1}$, and $W_{i}$ is the weight fraction of the mineral to dust in units of $\mathrm{g}$ of mineral $(\mathrm{g} \text { of dust })^{-1}$. Values for $K_{i}$, $m_{i}, A_{i}$, and $W_{i}$ for each of the mineral-dissolution reactions considered here are listed in Table 1. The function $f$ is given by

$f\left(\Delta G_{i}\right)=1-\exp \left[\left(n \times \Delta G_{i}\right) /(R \times T)\right]$

where

$\Delta G_{i}=R \times T \times \ln \left(Q_{i} / K E Q_{i}\right)$

and $n$ is an empirical parameter that in mineral-fluid reaction kinetics is most commonly set to 1 (e.g., Burch et al., 1993), $R$ is the gas constant, $Q_{i}$ is the reaction activity quotient (i.e., the ratio of the product of the reactants over the product of the species produced), and $K E Q_{i}$ is the equilibrium constant (Meng et al., 1995). Values of the kinetic constants for magnesite dissolution are available from Chou et al. (1989) (RS2 in Table 1). In highly acidic solutions, rates are independent of $\mathrm{pH}$ in the case of relatively fast dissolving minerals such as carbonates (Pokrovsky and Schott, 1999). Thus we set $\mathrm{pH}=3$ for the calculation of dissolution rates when $\mathrm{pH}<3$. The precipitation of secondary compounds $\left(\mathrm{MeSO}_{4}, \mathrm{Me}\left(\mathrm{NO}_{3}\right)_{2}\right.$, and $\mathrm{MeCl}_{2}, \mathrm{Me}=\mathrm{Ca}$ and $\mathrm{Mg}$ ) formed from the reactions of carbonate minerals with inorganic acids is assumed to be irreversible (Dentener et al., 1996; Song and Carmichael, 1999, 2001; McNaughton et al., 2008).

The hematite dissolution is also treated explicitly as a kinetic process (RS3 in Table 1), following Meskhidze et 
al. $(2003,2005)$. Thus, the three-stage kinetic process is considered for specification of hematite dissolution constants only, depending on the total amount of the hematite dissolved. The first $(0-0.8 \%$ of total oxide dissolved) and third (40-100\% of total oxide dissolved) stages are slower in dissolution compared to the second stage $(0.8-40 \%$ of total oxide dissolved).

Mezkhidze et al. (2003) have assumed that hematite is an important source for the dissolved iron over the North Pacific, because most of the iron in surface soil of the Gobi deserts is found in the form of hematite $\left(\mathrm{a}-\mathrm{Fe}_{2} \mathrm{O}_{3}\right)$ (Hseung and Jackson, 1952; Claquin et al., 1999). However, the assumption of hematite as the solely important source for dissolved iron may need to be revisited, as more comprehensive experimental data for chemical specificity of iron-rich dust become available (Cwiertny et al., 2008; Journet et al., 2008; Schroth et al., 2009; Fu et al., 2010). Here, the illite dissolution is also considered for specification of "structural iron", which is trapped in the crystal lattice of aluminosilicate minerals (RS4 in Table 1). Since the dissolution of ironcontaining minerals is very slow, the system consistently remains far from reaching equilibrium under the experimental conditions, hence no backward reaction is considered (i.e., $\left.f\left(\Delta G_{i}\right)=1\right)$.

\subsection{Iron emission}

We compiled an emission inventory for iron from dust and combustion sources (Fig. 1). The Gobi (northern China and southern Mongolia) and Taklimakan (western China) deserts are the dominant dust sources in East Asia during springtime (Sun et al., 2001). On the other hand, combustion sources show a broad distribution across rural areas of China, where domestic coal combustion is prevalent (Streets et al., 2003).

For the simulation of mineral aerosols, we use the daily dust emissions at $1.0^{\circ} \times 1.0^{\circ}$ compiled by Dentener et al. (2006). We applied a factor of 2.5 to the Asian dust emissions so that the total Asian dust emission for April 2001 is $321 \mathrm{Tg}$ (Fairlie et al., 2009). The dust emission fluxes were interpolated and represented in the 4 size bins $(0.05-0.63 \mu \mathrm{m}$, $0.63-1.25 \mu \mathrm{m}, 1.25-2.5 \mu \mathrm{m}, 2.5-10 \mu \mathrm{m}$ in radius) (Liu et al., 2005). The iron-containing mineral in dust aerosols is simplified with pure iron oxides $\left(\mathrm{Fe}_{2} \mathrm{O}_{3}\right)$ for base simulations (Exp1 and Exp2). We also examine sensitivity simulations with iron in illite (Exp3 and Exp4).

Iron from combustion sources could have a pronounced effect on aerosol iron solubility in addition to mineral dust aerosols (Chuang et al., 2005; Luo et al., 2008; Schroth et al., 2009). For this study, we develop an inventory for combustion-generated iron in $2001\left(1.2 \mathrm{Tg} \mathrm{Fe} \mathrm{year}^{-1}\right)$, using the fuel-consumption data and specific emission factors for individual fuel-use categories. The particulate emissions estimates are obtained from Ito and Penner (2005) and the emission factors used here are based on Luo et al. (2008). The conservative values for iron fractions in combustion-
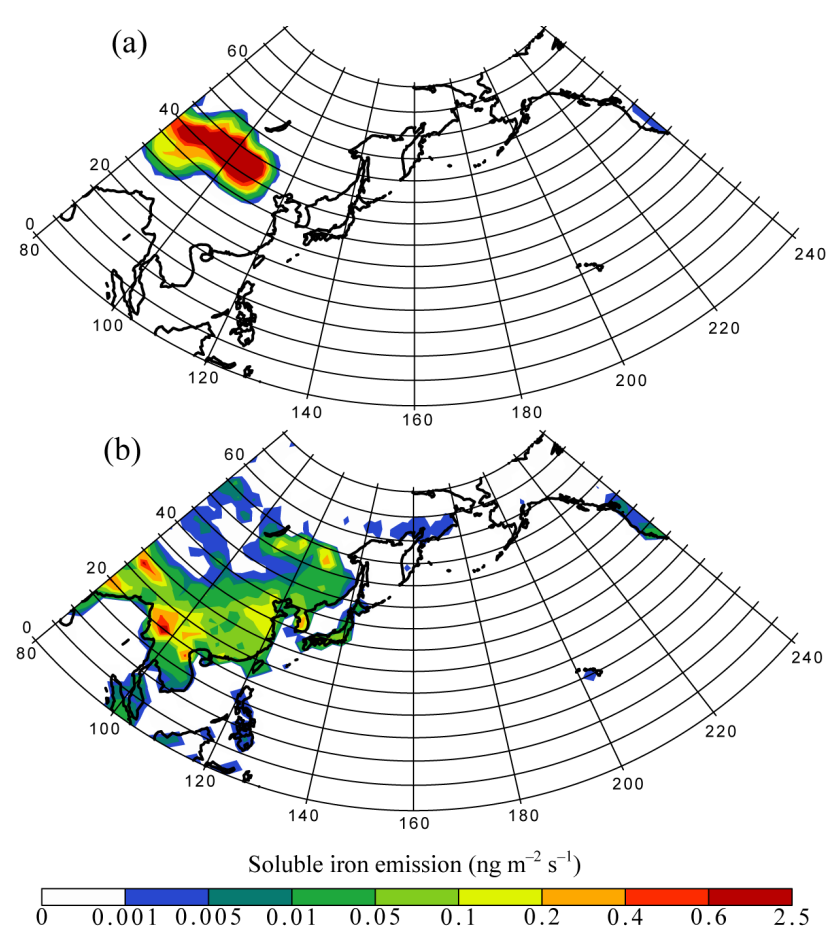

Fig. 1. Spatial distribution of monthly averaged soluble iron emission $\left(\mathrm{ng} \mathrm{m}^{-2} \mathrm{~s}^{-1}\right.$ ) from (a) desert and (b) combustion sources in April.

generated mineral aerosols from literature are used (Table 2). We assume that the inorganic matter in combustion includes all other materials that are not black carbon and organic matter. Therefore, the iron content in the fine and coarse particles does not exceed the estimated amount of inorganic matter. Following Luo et al. (2008), we use $4 \%$ and $0.45 \%$ in the initial conditions for the soluble iron fractions from the combustion and dust sources, respectively. The transport and deposition of the fine (coarse) iron particles from combustion sources are treated similarly to black carbon (coarsemode dust aerosol). The combustion-generated iron is assumed to have a labile chemical form in circumneutral solutions, and the iron on the particle surface is readily released into solutions (Schroth et al., 2009). They are assumed to be externally mixed with other aerosols in all of the size bins. We note that, however, internal mixing between dust and biomass burning particles may enhance the combustioniron solubility (Paris et al., 2010), but the process is still not well known.

\section{Model sensitivity studies and analysis}

The concentration, chemical composition and transport of mineral dust along with the East Asian continental outflow have been previously studied by a number of investigators, notably during the ACE-Asia field campaign (Huebert et al., 
Table 2. Iron Fractions of Combustion Emissions in Minerals.

\begin{tabular}{|c|c|c|c|}
\hline Source & Fine $(\%)$ & Coarse $(\%)$ & Reference \\
\hline \multicolumn{4}{|c|}{ Fossil Fuels } \\
\hline \multirow[t]{3}{*}{ Coal: power/industrial } & 7.5 & 9.4 & Mamane et al. (1986) \\
\hline & 7.6 & 8.1 & Olmez et al. (1988) \\
\hline & 4.5 & & Smith et al. (1979) \\
\hline Value used & 6.5 & 8.7 & \\
\hline Coal: residential & 0.1 & 0.1 & Luo et al. (2008) \\
\hline Coal briquettes & 1.6 & & Luo et al. (2008) \\
\hline \multirow[t]{4}{*}{ Oil boiler } & 0.13 & & Hildemann et al. (1991) \\
\hline & 1.7 & & Mamane et al. (1986) \\
\hline & 0.41 & 0.46 & Mamuro et al. (1979a) \\
\hline & 1.6 & 2.95 & Olmez et al. (1988) \\
\hline Value used & 0.96 & 1.16 & \\
\hline iron and steel & 1.22 & 15.7 & Mamuro et al. (1980) \\
\hline \multicolumn{4}{|c|}{ Biofuels } \\
\hline Agricultural wastes & 0.017 & 0.13 & Turn et al. (1997) \\
\hline Fuelwood & 0.0058 & 0.026 & Turn et al. (1997) \\
\hline \multicolumn{4}{|c|}{ Waste } \\
\hline \multirow[t]{2}{*}{ incinerator } & 0.59 & 0.61 & Mamuro et al. (1979b) \\
\hline & 0.22 & 1.7 & Olmez et al. (1988) \\
\hline Value used & 0.36 & 1.02 & \\
\hline \multicolumn{4}{|c|}{ Biomass burning } \\
\hline Savanna & 0.020 & & Maenhaut et al. (1996) \\
\hline Savanna & 0.030 & & Maenhaut et al. (1996) \\
\hline Ceraddo & 0.900 & & Ward et al. (1991) \\
\hline Ceraddo & 1.200 & & Ward et al. (1992) \\
\hline Ceraddo & 0.077 & & Yamasoe et al. (2000) \\
\hline Ceraddo & 0.045 & & Yamasoe et al. (2000) \\
\hline Extratropical forest & 0.100 & & Ward et al. (1991) \\
\hline Tropical forest & 0.900 & & Ward et al. (1991) \\
\hline Tropical forest & 0.100 & & Ward et al. (1992) \\
\hline Tropical forest & 0.031 & & Yamasoe et al. (2000) \\
\hline Tropical forest & 0.048 & & Yamasoe et al. (2000) \\
\hline \multirow[t]{2}{*}{ Tropical forest } & 0.100 & & Yamasoe et al. (2000) \\
\hline & & 3.4 & Luo et al. (2008) \\
\hline Value used & 0.296 & 3.4 & \\
\hline
\end{tabular}

2003). Here, we focus on the processes and factors that affect the iron dissolution. Vertical distribution of simulated aerosol concentrations is compared with measurements from the total aerosol sampler (TAS) aboard the C-130 aircraft for the non-sea-salt sulfate (Fig. 2a and b) and soluble calcium (Fig. 2c and d) in April 2001 (Huebert et al., 2003; Kline et al., 2004). The model results are averaged over the selected regions and the periods of sampling time in the aircraft flights, which covered large areas. The model demonstrates the ability to simulate the vertical structure of the observed anthropogenic sulfate and mineral dust aerosols. The absolute concentration of soluble calcium $\left(2 \pm 3 \mu \mathrm{g} \mathrm{m}^{-3}\right)$ is lower than the aircraft measurements $\left(4 \pm 6 \mu \mathrm{g} \mathrm{m}^{-3}\right)$, but the difference is within a standard deviation. More importantly, the model simulates the non-sea-salt sulfate concentrations well $\left(8 \pm 10 \mu \mathrm{g} \mathrm{m}^{-3}\right.$ for model vs. $8 \pm 7 \mu \mathrm{g} \mathrm{m}^{-3}$ for measurement), which drives the acid mobilization in the absence of alkaline dust. This sets the stage for investigating the iron solubility.

Two sets of simulations were performed with (Exp1 and Exp3) and without (Exp2 and Exp4) the alkaline dust minerals in the aqueous chemistry, respectively. In the first experiment (Exp1), the chemical composition of dust aerosols is assumed to be: $11 \% \mathrm{CaCO}_{3}, 5.5 \% \mathrm{MgCO}_{3}$, and $5 \%$ 
(a) NSS, C-130

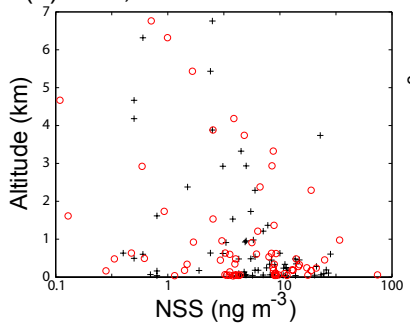

(c) Soluble calcium, C-130

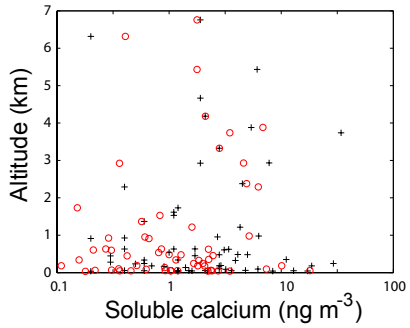

(b) NSS, C-130

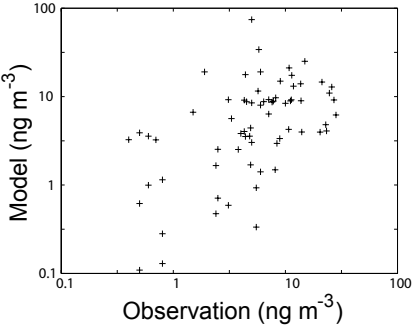

(d) Soluble calcium, C-130

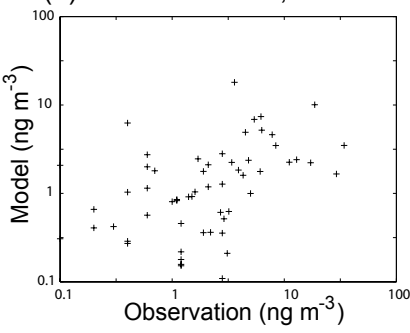

Fig. 2. Altitude distribution of simulated (red circles) versus measured (black crosses) concentration from ACE-Asia for (a) non-seasalt sulfate (NSS) and (c) soluble calcium during April 2001. Scatter plots are also shown for (b) non-sea-salt sulfate and (d) soluble calcium.

$\mathrm{Fe}_{2} \mathrm{O}_{3}$ (66 Tg Fe per year) (Duce and Tindale, 1991; Gillette et al., 1993; Meskhidze et al., 2005; McNaughton et al., 2008). Carbonate minerals $\left(\mathrm{MeCO}_{3}, \mathrm{Me}=\mathrm{Ca}\right.$ and $\left.\mathrm{Mg}\right)$ react with inorganic acid pollutants $\left(\mathrm{H}_{2} \mathrm{SO}_{4}, \mathrm{HNO}_{3}\right.$, and $\left.\mathrm{HCl}\right)$, producing thermodynamically more stable species $\left(\mathrm{MeSO}_{4}\right.$, $\mathrm{Me}\left(\mathrm{NO}_{3}\right)_{2}$, and $\left.\mathrm{MeCl}_{2}\right)$. Thus, the dust alkalinity reservoir is able to buffer the acidification linked to the anthropogenic emissions, although the $\mathrm{pH}$ buffering capacity of the original dust particles might be compromised during the long-range transport especially for submicron particles with large sulfate concentrations.

In the second experiment (Exp2), dust without carbonate minerals reacts with sulfate readily. Dust particles could become very acidic at the early stage of the transport before being neutralized by alkaline gases (Sullivan et al., 2007). Therefore, iron in aluminosilicate minerals potentially represents a significant source of soluble iron in the acidic environment (Cwiertny et al., 2008; Journet et al., 2008; Schroth et al., 2009).

In the last two experiments (Exp3 and Exp4), we explore the sensitivity of iron solubility to the iron mineralogy, because of the importance of chemical specificity of iron-rich dust. The dissolution rate of illite (RS4 in Table 1) and abundance of iron in dust $(1.8 \%)$ are taken from literature values (Nagy, 1995; Tessier, 1990; Skopp, 2000; Journet et al, 2008). The mixing state with alkaline dust is also examined for internal and external mixing in Exp3 and Exp4, respectively.
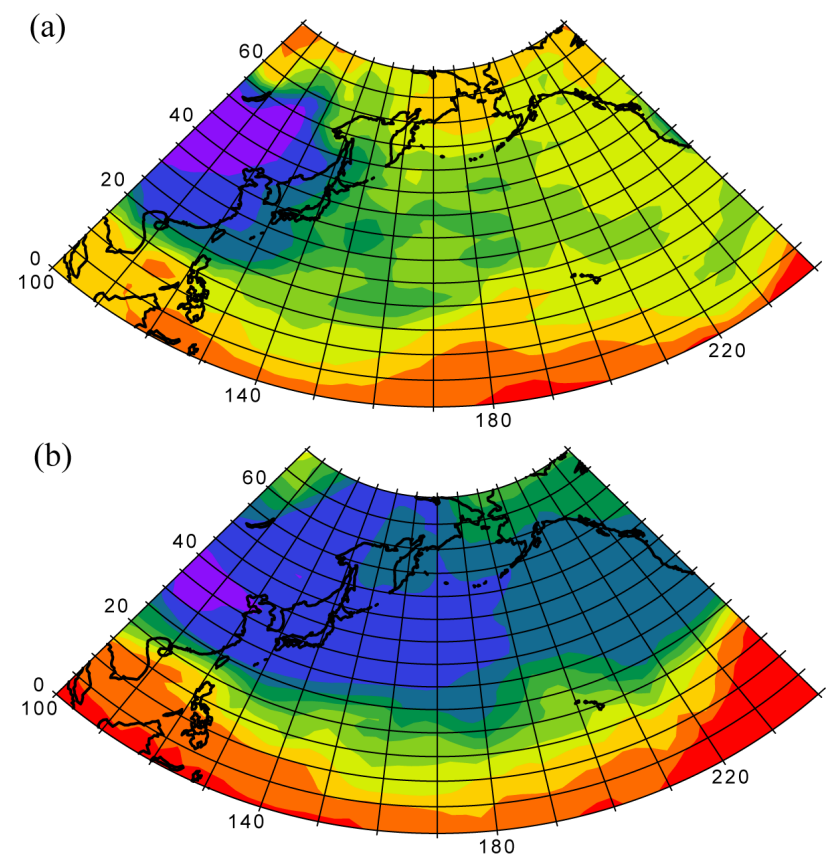

Fraction of sum of the secondary compounds in total calcium (\%)

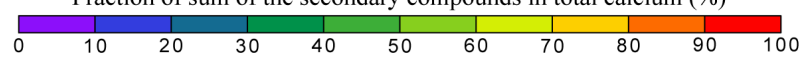

Fig. 3. Spatial distribution of the secondary compounds (i.e. sum of $\mathrm{CaSO}_{4}, \mathrm{CaCl}_{2}, \mathrm{Ca}\left(\mathrm{NO}_{3}\right)_{2}$ ) in total calcium (\%) in (a) the surface air and (b) the free troposphere during April 2001.

\subsection{Dust alkalinity}

Since calcite dissolves much faster than magnesite, it is the main contributor to the buffering effect of dust that neutralizes acidic anthropogenic aerosols in the long-range transport. In the model simulations including the alkaline dust in the aqueous chemistry (Exp1 and Exp3), calcite is converted to the secondary compounds (i.e. sum of $\mathrm{CaSO}_{4}, \mathrm{CaCl}_{2}$, $\left.\mathrm{Ca}\left(\mathrm{NO}_{3}\right)_{2}\right)$, as dust particles travel from the source regions in East Asia to the eastern North Pacific Ocean, as shown for April in Fig. 3. The estimated fraction (\%) of the secondary compounds in total calcium is significantly different between the surface air (Fig. 3a) and free troposphere (Fig. 3b). The low-altitude dust aged faster than the high-altitude dust, as a result of higher pollutant loadings near the surface (Tang et al., 2004). However, the simulated alkaline dust aerosols are only partly consumed by acids both at the surface (50-70\%) and in the free troposphere $(20-30 \%)$ during the transport. In the surface air, the percentage of the modeled secondary compounds are increased from $0-10 \%$ near the source region to $20-30 \%$ over south of the Korean Peninsula. In the free troposphere, only $20-30 \%$ of the calcite is converted to the secondary compounds $\left(\mathrm{CaSO}_{4}, \mathrm{Ca}\left(\mathrm{NO}_{3}\right)_{2}\right.$, and $\left.\mathrm{CaCl}_{2}\right)$ over the eastern North Pacific, which is consistent with the observation (McNaughton et al., 2008). 

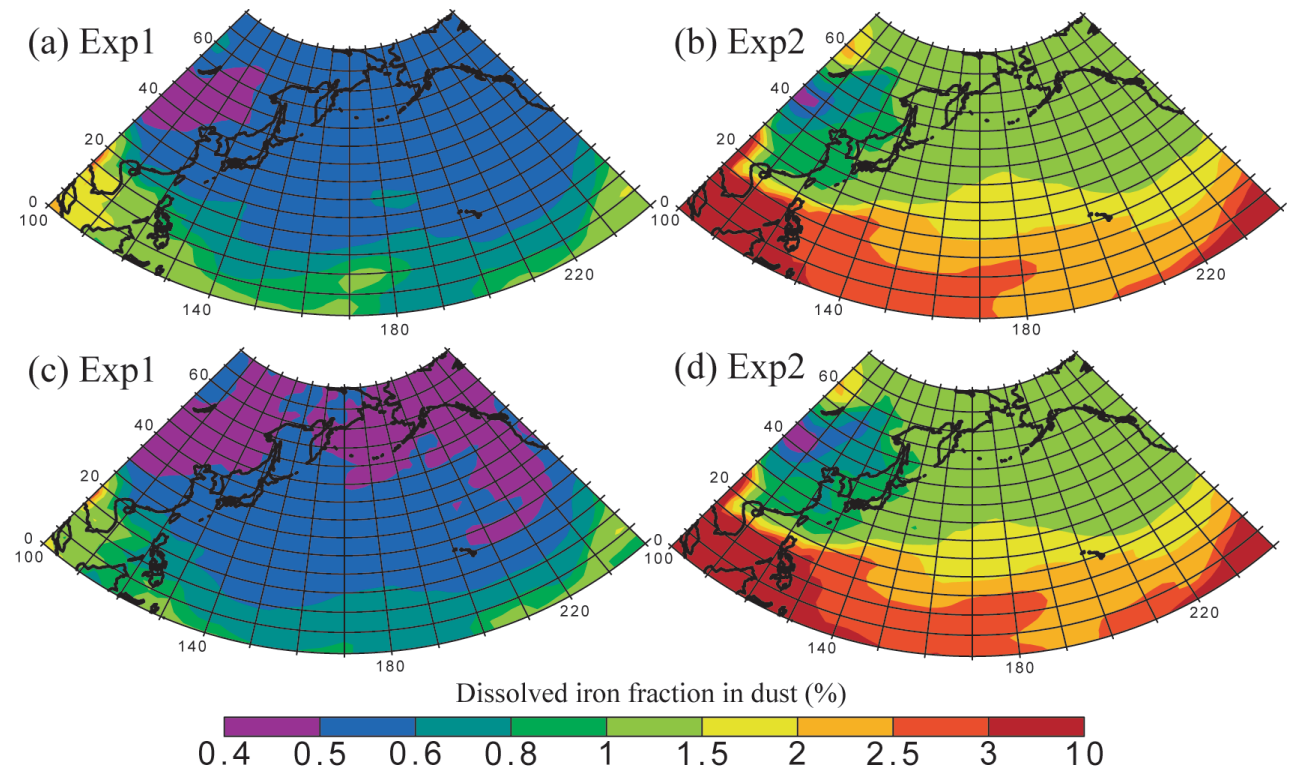

Fig. 4. Modeled dissolved iron fraction (DIF) in dust (\%) in the surface air during April 2001 for (a) the fine mode with the alkaline dust, (b) the fine mode without the alkaline dust, (c) the coarse mode with the alkaline dust, and (d) the coarse mode without the alkaline dust.
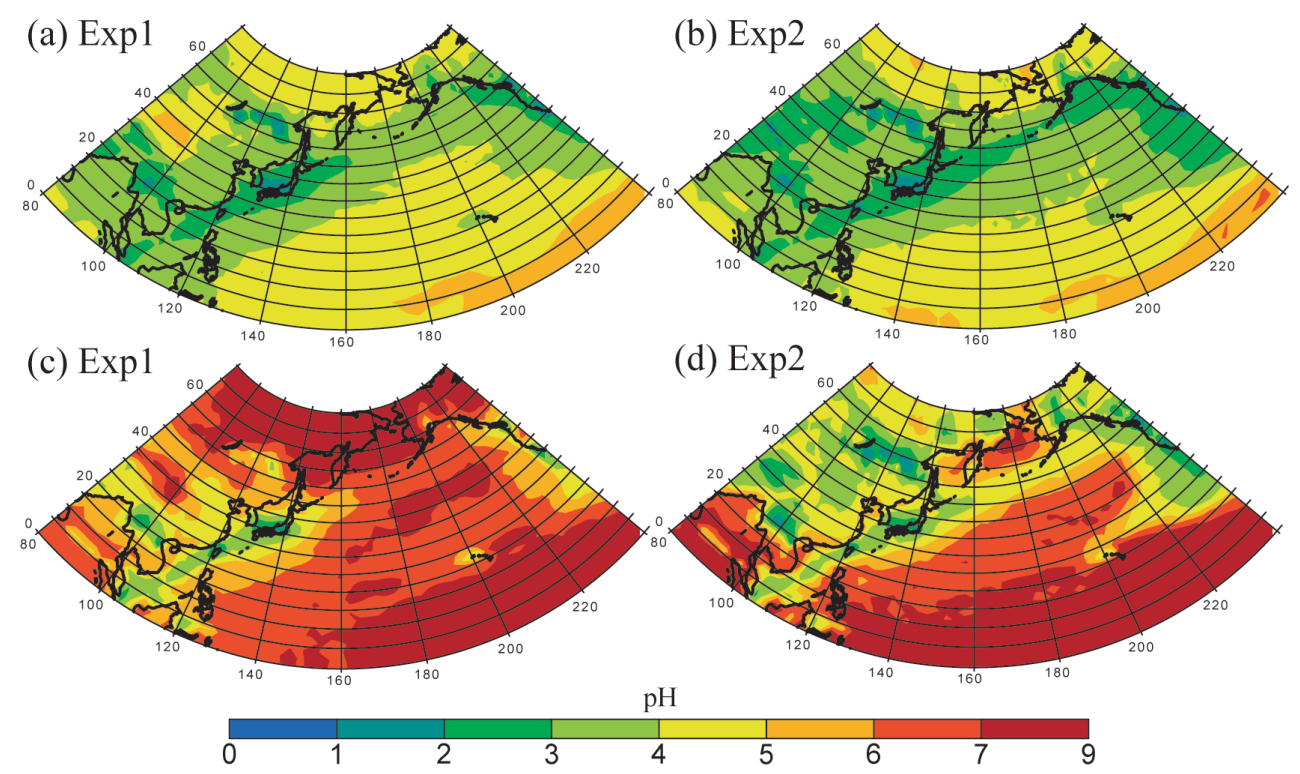

Fig. 5. Modeled pH in aerosols in the surface air during April 2001 for (a) the fine mode with the alkaline dust, (b) the fine mode without the alkaline dust, (c) the coarse mode with the alkaline dust, and (d) the coarse mode without the alkaline dust.

\subsection{Iron solubility}

The model simulations demonstrate a substantial reduction in the dissolved iron fraction (DIF) in dust when aerosol carbonate chemistry is included (Fig. 4). Here, the DIF in dust $(\%)$ was calculated using the total iron concentration from dust sources only. Emissions of alkaline gas (i.e., ammonia) exceed the amount that is needed to neutralize sul- fate and nitrate in large portions of East Asia (Tang et al., 2004). In our model calculations, a relatively high $\mathrm{pH}(>3)$, which may hinder the dissolution of iron-containing minerals, is predicted over the ammonia source regions (Fig. 5). In the absence of alkaline dust $(\operatorname{Exp} 2)$, lower $\mathrm{pH}(<3)$ is predicted near both dust and sulfur source regions. When aerosol carbonate chemistry is included (Exp1), however, the calcite-rich dust does not acidify near the dust source regions 
Table 3. Observed and Modeled Iron Fractional Solubility and Soluble Iron Concentration for the Fine Mode and Coarse mode (mean \pm standard deviation).

\begin{tabular}{lrrrr}
\hline Location & GOSAN $\left(33^{\circ} 17^{\prime} \mathrm{N}, 126^{\circ} 10^{\prime} \mathrm{E}\right)$ & Cruise $\left(24^{\circ} \mathrm{N}-28^{\circ} \mathrm{N}, 170^{\circ} \mathrm{E}-155^{\circ} \mathrm{W}\right)$ \\
\hline Particle size & Bulk & Bulk & Fine & Coarse \\
\hline Number of data & 27 & $23^{\mathrm{a}}$ & 18 & 18 \\
\hline \multicolumn{5}{c}{} \\
\hline
\end{tabular}

${ }^{a}$ Four distinct high values of the water-soluble fraction of iron in the total suspended particles were excluded.

b Alkaline dust aerosols are internally mixed with the iron-containing minerals.

c Alkaline dust aerosols are externally mixed with the iron-containing minerals.

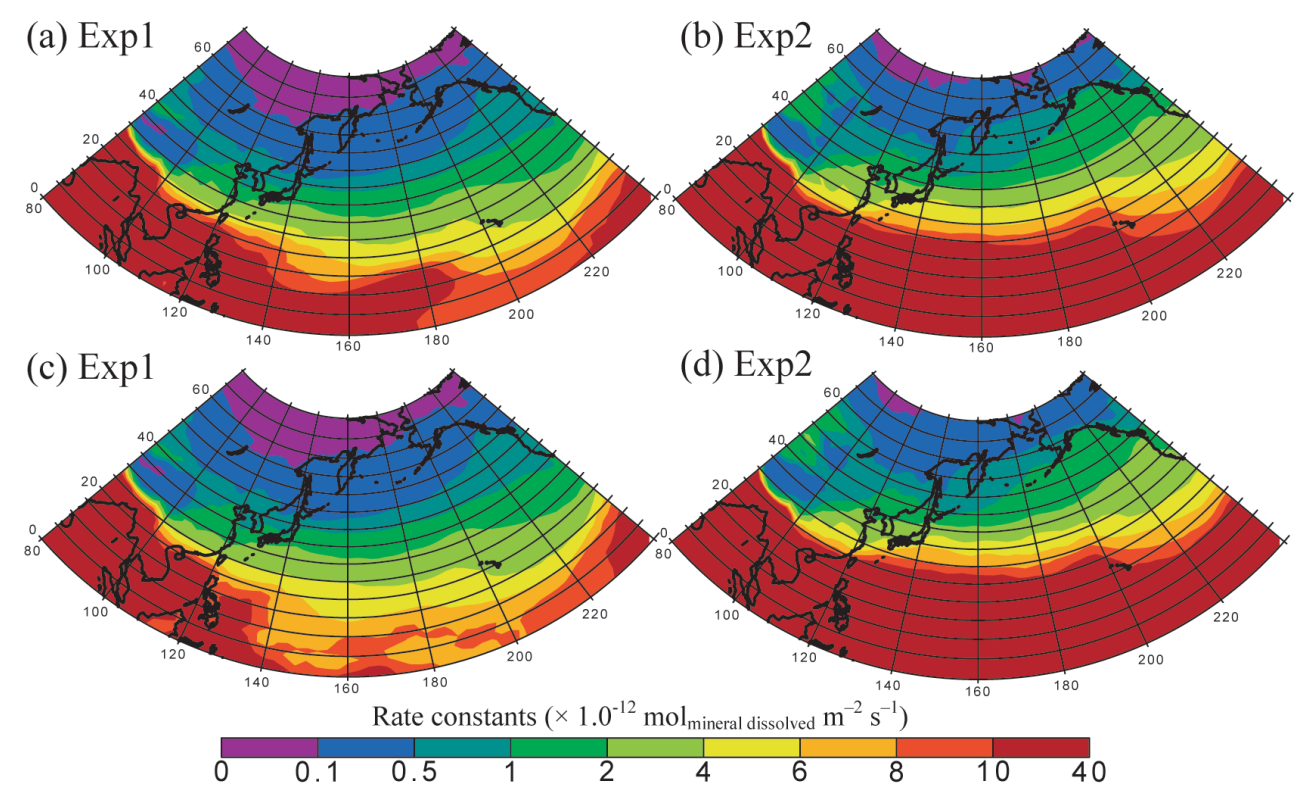

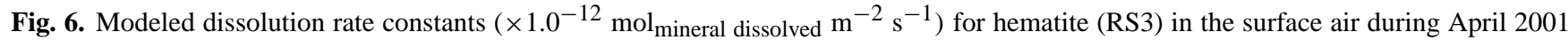
for (a) the fine mode with the alkaline dust, (b) the fine mode without the alkaline dust, (c) the coarse mode with the alkaline dust, and (d) the coarse mode without the alkaline dust.

due to the buffering ability of carbonate minerals. Thus the iron-containing mineral aerosols in Exp2 dissolve faster than those in Exp1, and also dissolve faster in some regions due to an accelerated dissolution rate at the second stage (Fig. 6).

Measurements taken at a regional sampling site (GOSAN) $\left(33^{\circ} 17^{\prime} \mathrm{N}, 126^{\circ} 10^{\prime} \mathrm{E}\right)$ on the west-end of Jeju Island, south of the Korean Peninsula, from 31 March to 2 May in 2001 have shown four extremely high values for the water-soluble iron fraction in the total suspended particles (6.45-12\%) during the time periods when the air masses originate from Japan (Duvall et al., 2008). Model results of the iron fractional solubility (Exp1 and 2) underestimate the mean and standard deviation when these values are included for comparison (Table 3). Here, the fractional solubility of aerosol iron (\%) was calculated using the total iron concentration from both dust and combustion sources. However, the comparison 


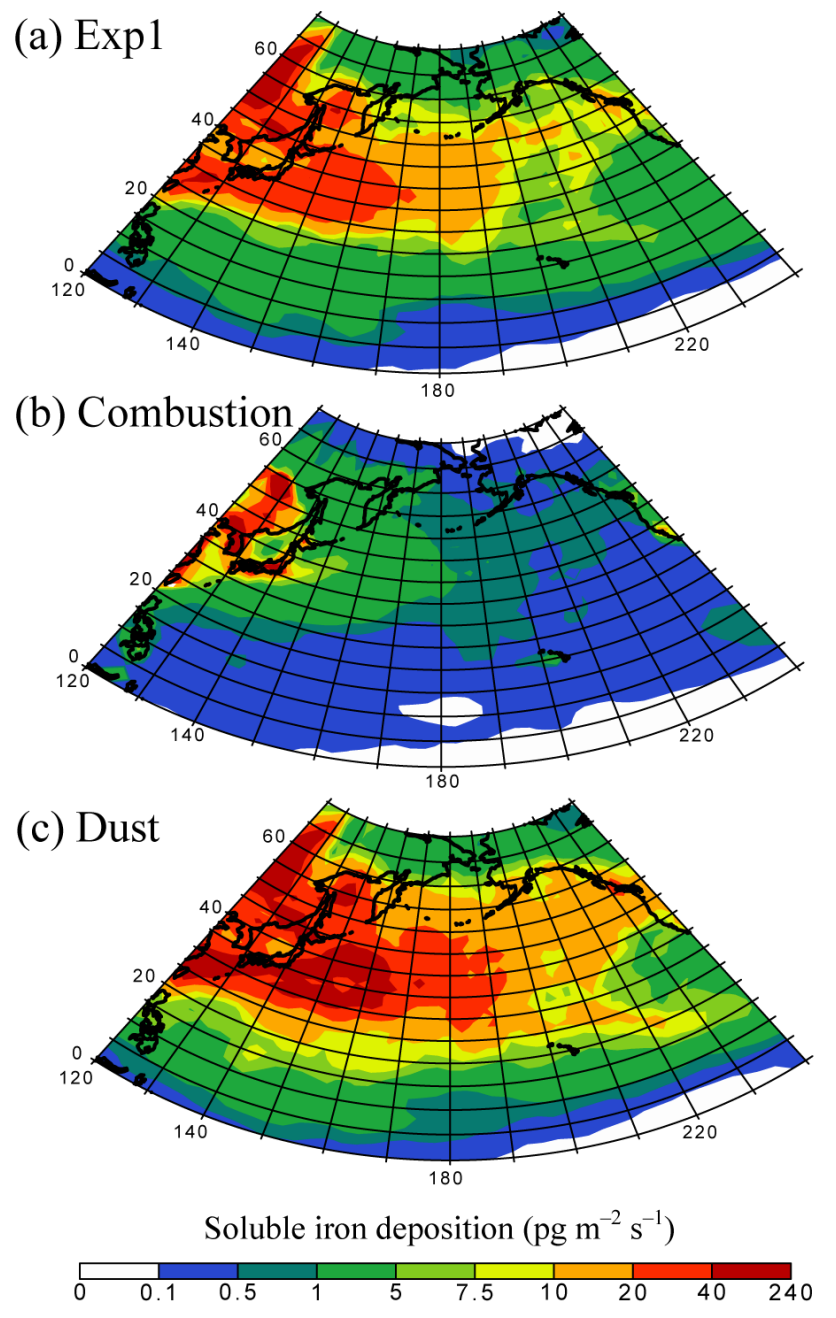

Fig. 7. Average soluble iron deposition $\left(\mathrm{pg} \mathrm{m}^{-2} \mathrm{~s}^{-1}\right)$ to the ocean from (a) dust source (Exp1), (b) combustion source, and (c) dust source with combination of Exp1 for coarse mode and Exp2 for fine mode during April 2001.

excluding the four extremes shows good agreement in the averaged iron fractional solubility (1.1-1.6\% for Exp1-2 vs. $1.4 \%$ for measurement). The model significantly underestimates the total soluble iron concentration $\left(6-8 \mathrm{ng} \mathrm{m}^{-3}\right.$ for Exp1-2) at the GOSAN site (26 $\mathrm{ng} \mathrm{m}^{-3}$ for measurement), which is located between the sources and remote conditions with a great gradient in aerosol concentration (Chen et al., 1997). It is probably because the coarse horizontal resolution of the global model does not account for the distinctive local geography and spatial variability, which could significantly affect the comparisons with the point-based daily measurements.

In our model, faster removal of larger particles leads to larger fractions of fine particles in total aerosols over the remote ocean (i.e., more soluble iron from combustion sources). Additionally, the buffering capacity of mineral aerosol in the fine mode is consumed more efficiently due to the preferential condensation of acids on smaller particles. As a result, the global model simulates higher iron fractional solubility for the fine mode (diameter $<2.5 \mu \mathrm{m}$ ) than that for the coarse mode (diameter $>2.5 \mu \mathrm{m}$ ) along the atmospheric transport to the eastern North Pacific Ocean. The onboard cruise measurements have reported that smaller particles have higher iron fractional solubility over the tropical Pacific Ocean between $24^{\circ} \mathrm{N}-28^{\circ} \mathrm{N}$ and $170^{\circ} \mathrm{E}-155^{\circ} \mathrm{W}$ from 9 to 26 April 2001 (Chen and Siefert, 2003; Hand et al., 2004). Similarly, the simulated iron fractional solubility for the fine mode is also higher than that for the coarse mode averaged over the cruise tracks (Table 3). When the alkaline dust chemistry is included (Exp1), the model estimate of the iron fractional solubility is in good agreement with measurements $(0.5 \%$ vs. $0.6 \pm 0.2 \%)$ for the coarse mode, while the model underestimates for the fine mode $(0.7 \%$ vs. $1.7 \pm 0.8 \%$ ). When the buffering ability of alkaline dust is neglected (Exp2), better agreement is obtained for the fine mode $(2.0 \%)$, but the model significantly overestimates for the coarse mode $(1.8 \%)$. These results may suggest that the iron-containing dust in the coarse mode is likely associated with calcite-rich dust, which is internally mixed with the hematite. On the other hand, the iron-containing dust in the fine mode is possibly associated with aluminosilicaterich minerals including iron substituted in the crystal lattice of alminosilicates, which are externally mixed with alkaline carbonate minerals (Sullivan et al., 2007). Thus we propose that smaller dust particles may yield increased amounts of soluble iron relative to larger particles due to possible variations in chemical mixing state of alkaline dust with ironcontaining minerals as a non-linear function of particle size. We note that some dust particles in the atmosphere are mineral aggregates composed of two or more minerals, such as aggregates of alminosilicate and gypsum, alminosilicate and calcite, and alminosilicate and iron oxides (Falkovich et al., 2001; Gao and Anderson, 2001; Shi et al., 2005). However, the representation of aggregation process of individual soil particles with different materials as well as chemical process of iron dissolution for different composition can be very complex and challenging for modeling. Thus, achieving a predictive capability for size-segregated aerosols of soluble iron will require further work involving laboratory experiments, modeling, and observations, such as spatial distribution of iron content in clays, size distribution data of chemical composition in mineral aerosols, and dissolution rates of iron from clay minerals.

\subsection{Soluble iron deposition}

In addition to mineral dust aerosols, iron from combustion sources could have a pronounced effect on aerosol iron solubility (Chuang et al., 2005; Luo et al., 2008; Schroth et al., 2009). Nevertheless, we estimate that average soluble iron deposition for the month of April 2001 from dust sources 

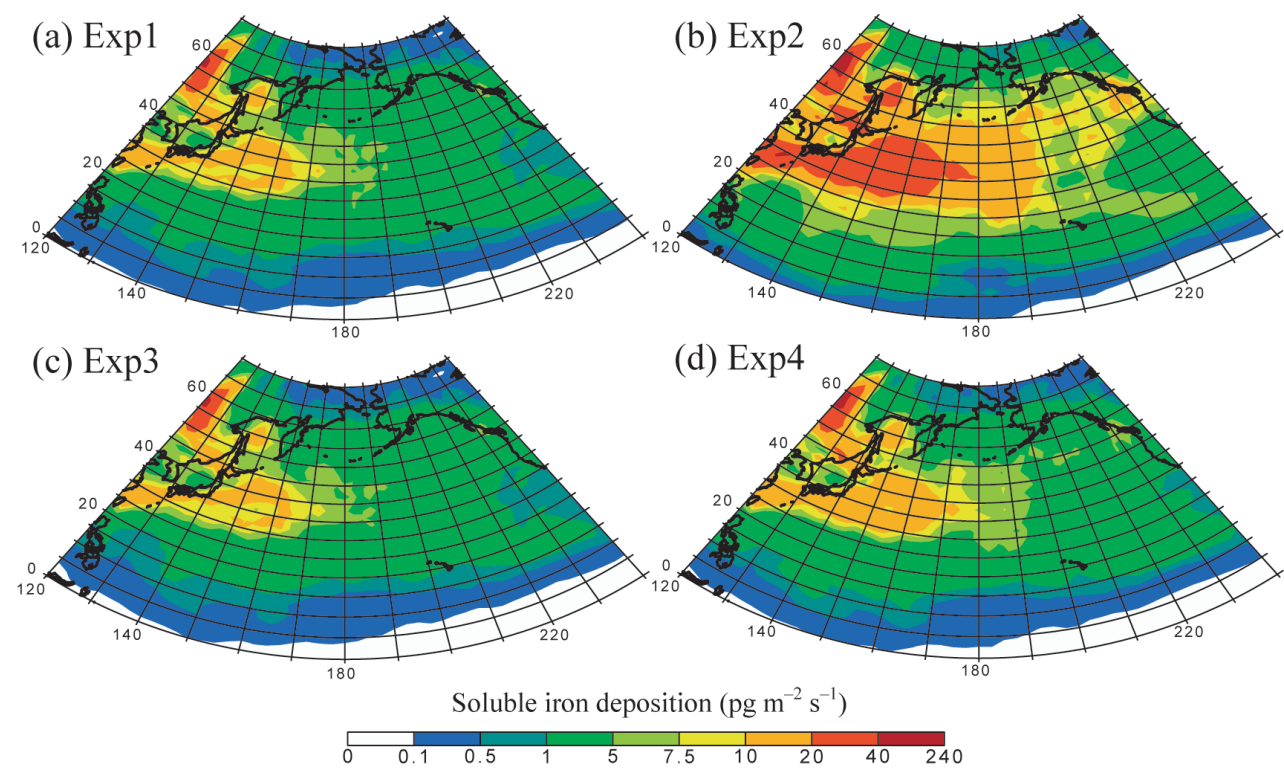

Fig. 8. Average soluble iron deposition $\left(\mathrm{pg} \mathrm{m}^{-2} \mathrm{~s}^{-1}\right.$ ) to the ocean from dust source for (a) hematite internally mixed with the alkaline dust (Exp1), (b) hematite externally mixed with the alkaline dust (Exp2), (c) illite internally mixed with the alkaline dust (Exp3), and (d) illite externally mixed with the alkaline dust (Exp4) for fine mode during April 2001.

is significantly higher $\left(5-20 \mathrm{pg} \mathrm{m}^{-2} \mathrm{~s}^{-1}\right.$ in Fig. $7 \mathrm{a}$ and $\left.\mathrm{c}\right)$ than that from the combustion sources $\left(0.5-1.0 \mathrm{pg} \mathrm{m}^{-2} \mathrm{~s}^{-1}\right.$ in Fig. 7b) over the eastern North Pacific Ocean, due to a more efficient long-range transport in the free troposphere.

The simulation of Exp1 underestimated the mass fraction of soluble iron in the fine mode to the total soluble iron concentration ( 0.5 for Exp1 vs. 0.8 for measurement in Table 3) over the Pacific Ocean. When we combine the iron deposition for fine particles from Exp2 with that for coarse particles from Exp1, we would be able to obtain a better agreement in the mass fraction (0.7) with the observation. The combined data set (Fig. 7c) is based on the assumption that chemical mixing state of iron-containing minerals with alkaline dust could be different between the fine and coarse particles. The mass fraction of dust in the fine-mode aerosols is small near the source regions, so that the resulting increases in iron deposition are small near the continents. However, it is noteworthy that the deposition of soluble iron from this scenario would become predominantly high $\left(10-20 \mathrm{pg} \mathrm{m}^{-2} \mathrm{~s}^{-1}\right)$ over the eastern North Pacific Ocean, due to a longer residence time of smaller particles.

Finally, we present the sensitivity of iron solubility in the fine-mode dust to the mineralogy of iron in simulations of Exp3 and Exp4. The faster dissolution rate of illite is partly compensated by the lower abundance of iron in dust. As a result, average soluble iron deposition $\left(\mathrm{pg} \mathrm{m}^{-2} \mathrm{~s}^{-1}\right)$ to the ocean from dust source for hematite internally mixed with the alkaline dust (Fig. 8a) is comparable to that for illite internally mixed with the alkaline dust (Fig. 8c). On the other hand, when the buffering effect of alkaline dust min- erals is excluded, a higher iron fraction in dust and a faster dissolution rate at the second dissolution stage with the assumption for hematite lead to substantially higher soluble iron deposition (Fig. 8b) than that for illite externally mixed with the alkaline dust (Fig. 8d). These results demonstrate that the iron solubility is sensitive to the chemical specification of iron-containing minerals in dust, especially when the iron-containing minerals are externally mixed with carbonate minerals.

\section{Summary and conclusions}

We investigated the impact of alkaline dust on the acid mobilization of iron. In this study, we introduced a specific mineral dissolution component to the global aerosol chemistry transport model. We have compiled the soluble iron emission data set from both dust and combustion sources. Through this study, we demonstrated that most alkaline dusts cannot be entirely consumed by acids during transport across the North Pacific Ocean. The mixing state of iron-containing aerosols with alkaline carbonate minerals and subsequent atmospheric chemical processing of the aerosols resulted in substantial differences in the iron solubility. The inclusion of alkaline dust in aqueous chemistry significantly limited the iron dissolution by inorganic acids in aerosol solution during the long-range transport. However, deserts in East Asia were still the dominant sources to the ocean deposition of total soluble iron over the N. Pacific, compared to combustion sources. 
Our results suggest that the iron dissolved from hematite in calcite-rich dust could be lower than that previously estimated, while aluminosilicate-rich minerals might provide a highly-soluble aerosol iron due to the strong acid mobilization of iron. Taking into account this non-linearity, we have improved our ability to estimate the iron fractional solubility in different particle sizes; but quantitative, episodic, and predictive capabilities of the soluble iron simulation remain challenging. Using this scenario, we showed that the deposition of soluble iron from smaller dust particles could be a dominant source of bioavailable iron over the eastern North Pacific Ocean. Thus while much of the research on understanding the role of mineral-dust iron in ocean productivity has focused on larger dust particles, further work would be required to study the atmospheric processing of mineral aerosols for different size modes in conjunction with sizefractionated mineralogy.

Conventionally, dust is assumed as the major supply of bioavailable iron with a constant solubility at $1-2 \%$ to the remote ocean, while Krishnamurthy et al. (2009) employed dust and combustion sources of Luo et al. (2008) with a 50\% reduction (from $4 \%$ to $2 \%$ ) in combustion iron initial solubility. However, the timing and location of the atmospheric input to the ocean may be different from those previously assumed. Past and future changes in aerosol supply of bioavailable iron might affect the availability of nutrients for phytoplankton production in the upper ocean, as global warming has been predicted to intensify stratification and reduce vertical mixing (Bopp et al., 2001; Ito and Kawamiya, 2010). Thus the feedback of climate change through ocean uptake of $\mathrm{CO}_{2}$ as well as via aerosol-cloud interaction, which may be induced by sulfate formation from dimethylsulfide (DMS) and carbon-containing aerosols production from the ocean biomass, might be modified by the inclusion of bioavailable iron deposition.

Acknowledgements. Support for this research was provided to A. Ito by Innovative Program of Climate Change Projection for the 21st Century (MEXT) and to Y. Feng by National Science Foundation (NSF), Atmospheric Sciences Program, under the grant ATM-0721142. Observational data from ACE-Asia were provided by NCAR/EOL under sponsorship of the National Science Foundation. http://data.eol.ucar.edu/.

Edited by: J. G. Murphy

\section{References}

Andronova, A. V., Gomes, L., Smirnov, V. V., Ivanov, A. V., and Shukurova, L. M.: Physicochemical characteristics of dust aerosols deposited during the Soviet-American eperiment (Tajikistan, 1989), Atmos. Environ., Part A: General Topics, 27(16), 2487-2493, 1993.

Arimoto, R., Zhang, X. Y., Huebert, B. J., Kang, C. H., Savoie, D. L., Prospero, J. M., Sage, S. K., Schloesslin, C. A.,Khaing, H. M., and Oh, S. N.: Chemical composition of atmo- spheric aerosols from Zhenbeitai, China, and Gosan, South Korea, during ACE-Asia, J. Geophys. Res., 109(D19), D19S04, doi:10.1029/2003JD004323, 2004.

Azuma, K. and Kametani, H.: Kinetics of dissolution of ferric oxide, Trans. Metall. Soc. AIME, 230, 853-862, 1964.

Baker, A. R. and Croot, P. L.: Atmospheric and marine controls on aerosol iron solubility in seawater, Mar. Chem., 120, 4-13, doi:10.1016/j.marchem. 2008.09.003, 2010.

Baker, A. R. and Jickells, T. D.: Mineral particle size as a control on aerosol iron solubility, Geophys. Res. Lett., 33, L17608, doi:10.1029/2006GL026557, 2006.

Blesa, M. A., Morando, P. J., and Regazzoni, A. E.: Chemical Dissolution of Metal Oxides, 401 pp., CRC Press, Boca Raton, Fla, 1994.

Bopp, L., Monfray, P., Aumont, O., Dufresne, J.-L., LeTreut, H., Madec, G., Terray, L., and Orr, J.: Potential impact of climate change on marine export production. Global Biogeochem. Cy., 15, 81-99, 2001.

Buck, C. S., Landing, W. M., and Resing, J. A.: Particle size and aerosol iron solubility: A high-resolution analysis of Atlantic aerosols, Mar. Chem., 120, 14-24, doi:10.1016/j.marchem.2008.11.002, 2010.

Burch, T. E., Nagy, K. L., and Lasaga, A. C.: Free energy dependence of albite dissolution kinetics at $80^{\circ} \mathrm{C}$ and $\mathrm{pH}$ 8.8, Chem. Geol., 105(1-3), 137-162, 1993.

Cama, J., Ayora, C., and Lasaga, A. C.: The deviation-fromequilibrium effect on dissolution rate and on apparent variations in activation energy, Geochim. Cosmochim. Acta, 63(17), 24812486, 1999.

Capaldo, K. P., Pilinis, C., and Pandis, S. N.: A computationally efficient hybrid approach for dynamic gas/aerosol transfer in air quality models, Atmos. Environ., 34, 3617-3627, 2000.

Chen, L.-L., Carmichael, G. R., and Hong, M.-S. et al.: Influence of continental outflow events on the aerosol composition at Cheju Island, South Korea, J. Geophys. Res., 102, 28551-28574, 1997.

Chen, Y. and Siefert, R.: Determination of various types of labile atmospheric iron over remote oceans, J. Geophys. Res., 108(D24), 4774, doi:10.1029/2003JD003515, 2003.

Chou L., Garrels, R. M., and Wollast, R.: Comparative study of the kinetics and mechanisms of dissolution of carbonate minerals, Chem. Geol., 78, 269-282, 1989.

Chuang, P. Y., Duvall, R. M., Shafer, M. M., and Schauer, J. J.: The origin of water soluble particulate iron in the Asian atmospheric outflow, Geophys. Res. Lett., 32, L07813, doi:10.1029/2004GL021946, 2005.

Claquin, T., Schulz, M., and Balkanski, Y. J.: Modeling the mineralogy of atmospheric dust sources, J. Geophys. Res., 104, 2224322256, 1999.

Cornell, R. M. and Schwertmann, U.: The Iron Oxides: Structure, Properties, Reactions, Occurrences and Uses, 573 pp., John Wiley, Hoboken, NJ, 1996.

Cwiertny, D. M., Baltrusaitis, J., Hunter, G. J., Laskin, A., Scherer, M. M., and Grassian, V. H.: Characterization and acid-mobilization study of iron-containing mineral dust source materials, J. Geophys. Res., 113, D05202, doi:10.1029/2007JD009332, 2008.

Dentener, F. J., Carmichael, G. R., Zhang, Y., Lelieveld, J., and Crutzen, P. J.: Role of mineral aerosol as a reactive surface in the global troposphere, J. Geophys. Res., 101(D17), 22869-22889, 
1996.

Dentener, F., Kinne, S., Bond, T., Boucher, O., Cofala, J., Generoso, S., Ginoux, P., Gong, S., Hoelzemann, J. J., Ito, A., Marelli, L., Penner, J. E., Putaud, J.-P., Textor, C., Schulz, M., van der Werf, G. R., and Wilson, J.: Emissions of primary aerosol and precursor gases in the years 2000 and 1750 prescribed data-sets for AeroCom, Atmos. Chem. Phys., 6, 4321-4344, doi:10.5194/acp6-4321-2006, 2006.

Duce, R. A. and Tindale, N. W.: Atmospheric transport of iron and its deposition in the ocean, Limnol. Oceanogr., 36(8), 17151726, 1991.

Duvall, R. M., Majestic, B. J., Shafer, M. M., Chuang, P. Y., Simoneit, B. R. T., and Schauer, J. J.: The water-soluble fraction of carbon, sulfur, and crustal elements in Asian aerosols and Asian soils, Atmos. Environ., 42, 5872-5884, 2008.

Fairlie, T. D., Jacob, D. J., Dibb, J. E., Alexander, B., Avery, M. A., van Donkelaar, A., and Zhang, L.: Impact of mineral dust on nitrate, sulfate, and ozone in transpacific Asian pollution plumes, Atmos. Chem. Phys., 10, 3999-4012, doi:10.5194/acp-10-39992010, 2010.

Falkovich, A. H., Ganor, E., Levin, Z., Formenti, P., and Rudich, Y.: Chemical and mineralogical analysis of individual mineral dust particles, J. Geophys. Res., 106, 18029-18036, 2001.

Feng, Y. and Penner, J. E.: Global modeling of nitrate and ammonium: Interaction of aerosols and tropospheric chemistry, J. Geophys. Res., 112, D01304, doi:10.1029/2005JD006404, 2007.

Fu, H., Cwiertny, D. M., Carmichael, G. R., Scherer, M. M., and Grassian, V. H.: Photoreductive dissolution of Fe-containing mineral dust particles in acidic media, J. Geophys. Res., 115, D11304, doi:10.1029/2009JD012702, 2010.

Fung, I. Y., Meyn, S. K., Tegen, I., Doney, S. C., John, J. G., and Bishop, J. K. B.: Iron supply and demand in the upper ocean, Global Biogeochem. Cy., 14(2), 697-700, 2000.

Gao, Y. and Anderson, J. R.: Characteristics of Chinese aerosols determined by individual-particle analysis, J. Geophys. Res., 106, 18037-18045, 2001.

Gillette, D. A., Patterson Jr., E. M., Prospero, J. M., and Jackson, M. L.: Soil aerosols, in Aerosol Effects on Climate, edited by S. G. Jennings, 77-109, Univ. of Ariz., Tucson, 1993.

Guieu, C., Bonnet, S., Wagener, T., and Loye-Pilot, M.-D: Biomass burning as a source of dissolved iron to the open ocean?, Geophys. Res. Lett., 22, L19608, doi:10.1029/2005GL022962, 2005.

Hand, J. L., Mahowald, N. M., Chen, Y., Siefert, R. L., Luo, C., Subramaniam, A., and Fung, I.: Estimates of atmosphericprocessed soluble iron from observations and a global mineral aerosol model: Biogeochemical implications, J. Geophys. Res., 109, D17205, doi:10.1029/2004JD004574, 2004.

Hildemann, L., Markowski, G., and Cass, G.: Chemical composition of emissions from urban sources of fine organic aerosol, Environ. Sci. Technol., 25, 744-759, 1991.

Huebert, B. J., Bates, T., Russell, P. B., Shi, G., Kim, Y. J., and Kawamura, K., Carmichael, G., and Nakajima, T.: An overview of ACE-Asia: Strategies for quantifying the relationships between Asian aerosols and their climatic impacts, J. Geophys. Res., 108(D23), 8633, doi:10.1029/2003JD003550, 2003.

Hseung, Y. and Jackson, M. L.: Mineral composition of the clay fraction: III Of some main soil groups of China, Soil Sci. Soc. Am. P., 16, 294-297, 1952.

Ito, A. and Kawamiya, M.: Potential impact of ocean ecosys- tem changes due to global warming on marine organic carbon aerosols, Global Biogeochem. Cy., 24, GB1012, doi:10.1029/2009GB003559, 2010.

Ito, A. and Penner, J. E.: Historical emissions of carbonaceous aerosols from biomass and fossil fuel burning for the period 1870-2000, Global Biogeochem. Cy., 19, GB2028, doi:10.1029/2004GB002374, 2005.

Ito, A., Sillman, S., and Penner, J. E.: Effects of additional nonmethane volatile organic compounds, organic nitrates, and direct emissions of oxygenated organic species on global tropospheric chemistry, J. Geophys. Res., 112, D06309, doi:10.1029/2005JD006556, 2007.

Ito, A., Sillman, S., and Penner, J. E.: Global chemical transport model study of ozone response to changes in chemical kinetics and biogenic volatile organic compounds emissions due to increasing temperatures: Sensitivities to isoprene nitrate chemistry and grid resolution, J. Geophys. Res., 114, D09301, doi:10.1029/2008JD011254, 2009.

Iwasaka, Y., Yamato, M., Imasu, R., and Ono, A.: Transport of Asian dust (KOSA) particles: importance of weak KOSA events on the geochemical cycle of soil particles, Tellus, 40B, 494-503, 1988.

Jacobson, M. Z.: Studying the effects of calcium and magnesium on size-distributed nitrate and ammonium with EQUISOLV II, Atmos. Environ., 33, 3635-3649, 1999.

Jickells, T. D., An, Z. S., Andersen, K. K., et al.: Global iron connections between desert dust, ocean biogeochemistry, and climate, Science, 308, 67-71, 2005.

Journet, E., Desboeufs, K. V., Caquineau, S., and Colin, J.-L.: Mineralogy as a critical factor of dust iron solubility, Geophys. Res. Lett., 35, L07805, doi:10.1029/2007GL031589, 2008.

Kline, J., Huebert, B., Howell, S., Blomquist, B., Zhuang, J., Bertram, T., and Carrillo, J.: Aerosol composition and size versus altitude measured from the C-130 during ACE-Asia, J. Geophys. Res., 109, D19508, doi:10.1029/2004JD004540, 2004.

Krishnamurthy, A., Moore, J. K., Mahowald, N., Luo, C., Doney, S. C., Lindsay, K., and Zender, C. S.: Impacts of increasing anthropogenic soluble iron and nitrogen deposition on ocean biogeochemistry, Global Biogeochem. Cy., 23, GB3016, doi:10.1029/2008GB003440, 2009.

Lasaga, A. C., Soler, J. M., Ganor, J., Burch, T. E., and Nagy, K. L.: Chemical-weathering rate laws and global geochemical cycles, Geochim. Cosmochim. Acta, 58(10), 2361-2386, 1994.

Liu, X., Penner, J. E., and Herzog, M.: Global modeling of aerosol dynamics: Model description, evaluation and interactions between sulfate and non-sulfate aerosols, J. Geophys. Res., 110, D18206, doi:10.1029/2004JD005674, 2005.

Luo, C., Mahowald, N., Bond, T., Chuang, P. Y., Artaxo, P., Siefert, R., Chen, Y., and Schauer, J.: Combustion iron distribution and deposition, Global Biogeochem. Cy., 22, GB1012, doi:10.1029/2007GB002964, 2008.

Maenhaut, W., Salma, I., Cafmeyer, J., Annegarn, H. J., and Andreae, M. O.: Regional atmospheric aerosol composition and sources in the eastern Transvaal, South Africa, and impact of biomass burning, J. Geophys. Res., 101, 23631-23650, 1996.

Mahowald, N. M., Baker, A. R., Bergametti, G., Brooks, N., Duce, R. A., Jickells, T. D., Kubilay, N., Prospero, J. M. and Tegen, I.: Atmospheric global dust cycle and iron inputs to the ocean, Global Biogeochem. Cy., 19, GB4025, 
doi:10.1029/2004GB002402, 2005.

Mahowald, N. M., Sebastian, E., Luo, C. et al.: Atmospheric iron deposition: global distribution, variability, and human perturbations, Annu. Rev. Mar. Sci., 1, 245-278, 2009.

Mamane, Y., Miller, J., and Dzubay, T.: Characterization of individual fly ash particles emitted from coal- and oil-fired power plants, Atmos. Environ., 20, 2125-2135, 1986.

Mamuro, T., Mizohata, A., and Kubota, T.: Elemental composition of suspended particles released from various boilers, J. Jpn. Soc. Air Pollut., 14, 296-303, 1979a (in Japanese).

Mamuro, T., Mizohata, A., and Kubota, T.: Elemental composition of suspended particles released in refuse incineration. J. Jpn. Soc. Air Pollut., 14, 190-196, 1979b (in Japanese).

Mamuro, T., Mizohata, A., and Kubota, T.: Elemental composition of suspended particles released from iron and steel works, J. Jpn. Soc. Air Pollut., 15, 69-76, 1980 (in Japanese).

Martin, J. H., Coale, K. H., Johnson, K. S. et al.: Testing the iron hypothesis in ecosystems of the equatorial Pacific Ocean, Nature, 371, 123-129, 1994.

Maxwell-Meier, K., Weber, R., Song, C., Orsini, D., Ma, Y., Carmichael, G. R., and Streets, D. G.: Inorganic composition of fine particles in mixed mineral dust-pollution plumes observed from airborne measurements during ACE-Asia, J. Geophys. Res., 109, D19S07, doi:10.1029/2003JD004464, 2004.

McNaughton, C. S., Clarke, A. D., Kapustin, V., Shinozuka, Y., Howell, S. G., Anderson, B. E., Winstead, E., Dibb, J., Scheuer, E., Cohen, R. C., Wooldridge, P., Perring, A., Huey, L. G., Kim, S., Jimenez, J. L., Dunlea, E. J., DeCarlo, P. F., Wennberg, P. O., Crounse, J. D., Weinheimer, A. J., and Flocke, F.: Observations of heterogeneous reactions between Asian pollution and mineral dust over the Eastern North Pacific during INTEX-B, Atmos. Chem. Phys., 9, 8283-8308, doi:10.5194/acp-9-8283-2009, 2009.

Meng, Z., Seinfeld, J. H., Saxena, P., and Kim, Y. P.: Atmospheric gas aerosol equilibrium: IV. Thermodynamics of carbonates, Aerosol Sci. Technol., 23, 131-154, 1995.

Meskhidze, N., Chameides, W. L., Nenes, A. and Chen, G.: Iron mobilization in mineral dust: Can anthropogenic $\mathrm{SO}_{2}$ emissions affect ocean productivity?, Geophys. Res. Lett., 30(21), 2085, doi:10.1029/2003GL018035, 2003.

Meskhidze, N., Chameides, W. L., and Nenes, A.: Dust and pollution: A recipe for enhanced ocean fertilization?, J. Geophys. Res., 110, D03301, doi:10.1029/2004JD005082, 2005.

Mills, M. M., Ridame, C., Davey, M., La Roche, J., and Geider, R. J.: Iron and phosphorus co-limit nitrogen fixation in the eastern tropical north Atlantic, Nature, 429, 292-294, 2004.

Nagy, K. L.: Dissolution and precipitation kinetics of sheet silicates, in Chemical Weathering Rates of Silicate Minerals, Rev. Mineral., vol. 31, 174-233, Mineral. Soc. of Am., Washington, DC, 1995.

Nishikawa, M., Kanamori, S., Kanamori, N., and Mizoguchi, T.: Kosa aerosol as eolian carrier of anthropogenic material, Sci. Total Environ., 107, 13-27, 1991.

Olmez, I., Sheffield, A., Gordon, G., Houck, J., Pritchett, L., Cooper, J., Dzubay, T. G., and Bennett, R.: Compositions of particles from selected sources in Philadelphia for receptor modeling applications, J. Air Pollut. Control Assoc., 38, 1392-1402, 1988.

Paris, R., Desboeufs, K. V., Formenti, P., Nava, S., and Chou, C.:
Chemical characterisation of iron in dust and biomass burning aerosols during AMMA-SOP0/DABEX: implication for iron solubility, Atmos. Chem. Phys., 10, 4273-4282, doi:10.5194/acp10-4273-2010, 2010.

Pokrovsky, O. S. and Schott, J.: Processes at the magnesiumbearing carbonates/solution interface. II. Kinetics and mechanism of magnesite, Geochim. Cosmochim. Acta, 63, 881-897, 1999.

Rotman, D. A., Atherton, C. S., Bergmann, D. J., et al.: IMPACT, the LLNL 3-D global atmospheric chemical transport model for the combined troposphere and stratosphere: Model description and analysis of ozone and other trace gases, J. Geophys. Res., 109, D04303, doi:10.1029/2002JD003155, 2004.

Schroth, A. W., Crusius, J., Sholkovitz, E. R., and Bostick, B. C.: Iron solubility driven by speciation in dust sources to the ocean, Nat. Geosci., 2, 337-340, doi:10.1038/ngeo501, 2009.

Sedwick, P. N., Sholkovitz, E. R., and Church, T. M.: Impact of anthropogenic combustion emissions on the fractional solubility of aerosol iron: Evidence from the Sargasso Sea, Geochem. Geophys. Geosyst., 8, Q10Q06, doi:10.1029/2007GC001586, 2007.

Shao, L. Y., Li, W. J., Yang, S. S., Shi, Z. B., and Lü, S. L.: Mineralogical characteristics of airborne particles collected in Beijing during a severe Asian dust storm period in spring 2002, Science in China(D), 50(6), 953-959, 2007.

Shi, Z., Shao, L., Jones, T. P., and Lu, S.: Microscopy and mineralogy of airborne particles collected during severe dust storm episodes in Beijing, China, J. Geophys. Res., 110, D01303, doi:10.1029/2004JD005073, 2005.

Shi, Z., Krom, M. D., Bonneville, S., Baker, A. R., Jickells, T. D., and Benning, L. G.: Formation of iron nanoparticles and increase in iron reactivity in mineral dust during simulated cloud processing, Environ. Sci. Technol., 43, 6592-6596, 2009.

Sholkovitz, E. R., Sedwick, P. N., and Church, T. M.: Influence of anthropogenic combustion emissions on the deposition of soluble aerosol iron to the ocean: Empirical estimates for island sites in the North Atlantic, Geochim. Cosmochim. Acta, 73, 3981-4003, 2009.

Siefert, R. L., Johansen, A. M., and Hoffmann, M. R.: Chemical characterization of ambient aerosol collected during the southwest monsoon and intermonsoon seasons over the Arabian Sea: Labile-Fe(II) and other trace metals, J. Geophys. Res., 104, 3511-3526, 1999.

Skopp, J. M.: Physical properties of primary particles, in Handbook of Soil Science, edited by: Summer, M. E., 3-17, CRC Press, Boca Raton, Fla., 2000.

Smith, R., Campbell, J., and Nielson, K.: Characterization and formation of submicron particles in coal-fired plants, Atmos. Environ., 13, 607-617, 1979.

Solmon, F., Chuang, P. Y., Meskhidze, N., and Chen, Y.: Acidic processing of mineral dust iron by anthropogenic compounds over the North Pacific Ocean, J. Geophys. Res., 114, D02305, doi:10.1029/2008JD010417, 2009.

Song, C. H. and Carmichael, G. R.: The aging process of naturally emitted aerosol (sea-salt and mineral aerosol) during long range transport, Atmos. Environ., 33(14), 2203-2218, 1999.

Song, C. H. and Carmichael, G. R.: Gas-particle partitioning of nitric acid modulated by alkaline aerosol, J. Atmos. Chem., 40(1), 1-22, 2001.

Streets, D. G., Bond, T. C., Carmichael G. R., et al.: An inventory of 
gaseous and primary aerosol emissions in Asia in the year 2000, J. Geophys. Res., 108(D21), 8809, doi:10.1029/2002JD003093, 2003.

Sullivan, R. C., Guazzotti, S. A., Sodeman, D. A., and Prather, K. A.: Direct observations of the atmospheric processing of Asian mineral dust, Atmos. Chem. Phys., 7, 1213-1236, doi:10.5194/acp-7-1213-2007, 2007.

Sun, J., Chang, M., and Liu, T.: Spatial and temporal characteristics of dust storms in China and its surrounding regions, 19601999: Relations to source area and climate, J. Geophys. Res., 106, 18331-18344, 2001.

Tang, Y. H., Carmichael, G. R., Seinfeld, J. H., et al.: Threedimensional simulations of inorganic aerosol distributions in east Asia during spring 2001, J. Geophys. Res., 109, D19S23, doi:10.1029/2003JD004201, 2004.

Tessier, D.: Behavior and microstructure of clay minerals, in Soil Colloids and Their Associations in Aggregates, edited by: De Boodt, M. F., Hayes, M., and Herbillon, A., 347-415, Springer, New York, 1990.

Turn, S. Q., Jenkins, B. M., Chow, J. C., Pritchett, L. C., Cambell, D., Cahill, T., and Whalen, S. A.: Elemental characterization of particulate matter emitted from biomass burning: Wind tunnel derived source profiles for herbaceous and wood fuels, J. Geophys. Res., 102, 3683-3699, 1997.

Ward, D. E., Setzer, A. W., Kaufman, Y. J., and Rasmussen, R. A.: Characteristics of smoke emissions from biomass fires of the Amazon region - BASE-A experiment, in: Global Biomass Burning: Atmospheric, Climatic, and Biospheric Implications, edited by: Levine, J. S., 394-402, MIT Press, Cambridge, MA, 1991.
Ward, D. E., Susott, R. A., Kauffman, J. B., Babbitt, R. E., Cummings, D. L., Dias, B., Holben, B. N., Kaufman, Y. J., Rasmussen, R. A., and Setzer, A. W.: Smoke and fire characteristics for cerrado and deforestation burns in Brazil: BASE-B experiment, J. Geophys. Res., 97, 14601-14619, 1992.

Yamasoe, M. A., Artaxo, P., Miguel, A. H., and Allen, A. G.: Chemical composition of aerosol particles from direct emissions of vegetation fires in the Amazon Basin: Water-soluble species and trace elements, Atmos. Environ., 34, 1641-1653, 2000.

Zhang, D., Shi, G.-Y., Iwasaka, Y., and Hu, M.: Mixture of sulfate and nitrate in coastal atmospheric aerosols: Individual particle studies in Qingdao $\left(36^{\circ} 04^{\prime} \mathrm{N}, 120^{\circ} 21^{\prime} \mathrm{E}\right)$, China, Atmos. Environ., 34, 2669-2679, 2000.

Zhu, X. R., Prospero, J. M., Millero, F. J., Savoie, D. L., and Brass, G. W.: The solubility of ferric ion in marine mineral aerosol solutions at ambient relative humidities, Mar. Chem., 38, 91-107, 1992.

Zhuang, G., Yi, Z., Duce, R. A., and Brown, P. R.: Link between iron and sulphur cycles suggested by detection of $\mathrm{Fe}$ (II) in remote marine aerosols, Nature, 355, 537-539, 1992.

Zinder, B., Furrer, G., and Stumm, W.: The coordination chemistry of weathering: II. Dissolution of Fe(III) oxides, Geochim. Cosmochim. Acta, 50(9), 1861-1869, 1986. 